\title{
The Tragedy of Jacob by Dena Curtis
}

\author{
Alexandra Garcia
}

On the fifth May this year, Dena Curtis' striking short film, Jacob, turns nine. Also commemorating its ninth anniversary on the thirteenth of February this year is the Rudd government's apology to the Aboriginal and Torres Strait Islander community for the tragedies that unfolded throughout the Stolen Generations. Perhaps these two dates are what inspired the airing on the twelfth of April of Jacob in NITV's The New Black, a compilation of short films directed by Aboriginal and Torres Strait Islander individuals, exploring culture, country and history. Perhaps the program was aired simply to remind the Australian public of the expansive talents of this land's Indigenous peoples.

Regardless of purpose, there is no denying that Curtis' Jacob is raw and honest in its reflections of the tragedies inflicted upon the Aboriginal community during this shameful period of Australian history. Its timely airing reacquaints viewers with only a fraction of the realities that have afflicted Aboriginal communities in the past, especially during the period of the Stolen Generations from 1910 to 1970, and in the present. Curtis' exploration throughout Jacob of poor mental health as a result of sexual abuse, as well as life for Indigenous citizens during the Stolen Generations, is no doubt the most heartbreaking, honest and confronting eleven minutes of film to hit Australian television screens in recent times.

Curtis' education at the Australian Film Television and Radio School and her roles in television media as a producer and director, combined with her own experiences as an Aboriginal woman and her work in rural and suburban Aboriginal communities, allows for her to construct film and narrative through a professional and personal lens. Her films have always dealt with confronting themes, challenging her viewers to consider varying cultural and social perspectives. Her films not only prompt viewers to be conscious of Aboriginal narrative, but also to laugh, cry and hurt - to feel emotion in ways that pushes the individual out of their viewing comfort zone.

Her choice of setting in her films are environments that Curtis' audiences would be familiar with the family home, the Australian outback and the suburban streets, making her work consumable for audiences both within and beyond the Aboriginal community. Her prior work in Hush and Nan and a Whole Lot of Trouble are tales set in the family home, loaded with charisma, humor, and - in contrast - a confrontation with the reality of the threat of losing independence, and of course, the controversy of shifting values and defying Indigenous cultural norms. Challenging the 
lightheartedness of these films, Jacob slams its audience with the severity of the Stolen Generation atrocities, addressing the heartrending reality and despair of the Indigenous people living through the Stolen Generations. These works embody Curtis' ability to utilise her skills as a director and identity as an Aboriginal woman to deliver an honest and impactful portrayal of contemporary Aboriginal narrative.

Situated in Central Australia - the homeland of her own clan's of heritage, the Warmungu and the Warlpiri clans - Curtis introduces Max and George, two Aboriginal men, who are working on fences when they receive news that Max's wife, Gina, has given birth to a baby boy. Naming him Jacob, Max returns home to meet his new baby boy, however his excitement is soon extinguished once he learns that his baby is white. Harbouring frustration and resentment towards Gina and Jacob due to the colour of Jacob's skin, Max struggles to bond with his baby boy. He soon retires these feelings when he discovers that Gina's offspring was the fruit of a sexual assault at the hands of a white farmer. Gina, in contrast, conceals these feelings until she reaches a breaking point, leading her to put Jacob in an extremely distressing situation.

The plight of Gina and Max is not exclusive to their home, with the unregulated employment and forced labour of Indigenous men, women and children, prior to and during the Stolen Generations, becoming a feeding ground for white, sexually abusive employers (Robinson, 2002). The abuse was not exclusive to farming contexts - extending its branches into the pearling industry (Robinson, 2002) and the missionary homes of stolen children (NITV, 2017), this sex abuse perpetuated a cycle of abuse that still plagues Indigenous communities today (Atkinson, 1990). These instances of violence within Indigenous communities prove to be a negative occurrence for both the perpetrator and the victim. The former is often introduced to the prison system, as opposed to being rehabilitated to quell the abusive behaviour, while the latter continue to find themselves in psychological distress and further situations of abuse, whether they remain the victim or end up 'becoming violent themselves' (Atkinson 1990, p. 4). Gina suffers the aftermath of this violence onscreen, cramming Jacob into an anthill in a moment of desperation to separate herself from the token of her rape. The harrowing vision of Gina's distress is alarming - though it is only a mere taste of the aftermath that follows the myriad of violence dwelling within the community.

The sexual abuse of Indigenous women, such as Gina, led to many women bearing children that were eventually taken from their homes by the state, in a bid to assimilate Indigenous children into white society. These policies were constructed with the white ideals of Aboriginal and Torres Strait Islander parents being 'incompetent' and 'neglectful of their children' (O'Shane, 1995, p. 26). The removal of these children from their parents was to orchestrate their conforming to a white European lifestyle, in a bid to shape them into what was perceived to be 'worthwhile adults' (O'Shane, 1995, p. 26). The removal of Indigenous children from their homes, and ultimately, their culture, led to the dispossession of a generation of Indigenous people, who in most cases were never able to reconnect with their biological parents (Australian Human Rights Commission, 1997). 'Low self-esteem' (Creative Spirits, 2017, para. 3), 'substance and alcohol abuse' (Creative Spirits, 2017, para. 11), 'loss of identity' (Creative Spirits, 2017, para. 4) and 'internal guilt' (Creative Spirits, 2017, para. 8) are only a few of the effects suffered by the Stolen Generations following their removal from their homes. Although Jacob's removal from his home is not addressed in the film, Curtis' decision to set Jacob in Central Australia in 1940 places him in the appropriate context, 
confronting her audience with the implication that Jacob will inevitably be removed from Gina and Max's home.

Curtis brings her audience into a world of devastation through Jacob, confronting her audience with the reality of the horrors of the Stolen Generations. In engaging with film and identity to keep awareness of the sexual abuse and dispossession that ensued within this dark moment of history alive in Australian homes today, Curtis has delivered a truly emotional and important message to televisions across the country. Jacob is a gift to the victims of the Stolen Generations, whose memory will forever be remembered in this remarkable piece of film.

\section{References and notes}

Atkinson, J., 'Violence in Aboriginal Australia: Part 2', Aboriginal and Islander Health Worker Journal 1990, vol. 14, no. 3, pp. 4-27.

Creative Spirits Stolen Generation - Effects and Consequences, https://www.creativespirits.info/aboriginalculture/politics/stolen-generations-effects-andconsequences\#axzz4ela4qj8q (accessed on 20 April 2017).

Human Rights and Equal Opportunity Commission 1997, Bringing them home: the separation of Aboriginal and Torres Strait Islander children from their families, Canberra, https://www.youtube.com/watch?v=S182VMuuKI0 (accessed on 21 April 2017).

NITV 2017, Aboriginal sex abuse victims become first group in Australia to win compensation, Sydney, http://www.sbs.com.au/nitv/nitv-news/article/2017/02/16/aboriginal-sex-abuse-victimsbecome-first-group-australia-win-compensation (accessed on 20 April 2017).

O'Shane, P., 'The Psychological Impact of White Settlement on Aboriginal People', Aboriginal and Islander Health Worker Journal, 1995, vol. 19, no. 3, pp. 24-29.

Robinson, S., 'The Unregulated Employment of Aboriginal Children in Queensland, 1842-1902', Labour History, 2002, no. 82, pp. 1-15. https://doi.org/10.2307/27516838 